\title{
KNOWLEDGE, ATTITUDE, AND BEHAVIOR ABOUT ABORTION AMONG ADULT WOMEN AT PEUNAYONG DISTRICT, BANDA ACEH, INDONESIA
}

\author{
EKA RUSDIANTO GUNARDI*, ERIK A RAHMAN, BIRAN AFFANDI, MUHAMMAD IKHSAN
}

Department of Obstetrics and Gynecology, Faculty of Medicine, Dr. Cipto Mangunkusumo National General Hospital, Universitas Indonesia, Jakarta, Indonesia. Email: eka_dhikita@yahoo.co.id

Received: 02 March 2019, Revised and Accepted: 14 May 2019

\section{ABSTRACT}

Objective: Every year approximately 13\% (78,000) of maternal death caused by unsafe abortion. Indonesia Family Planning Association predicts 2.5 million abortions per year and 1.5 million of them committed by teenagers. Adolescent reproductive health problems are more alarming year by year. Sexual behavior tends to be permissive and bold with limited knowledge of reproductive health has increased the risk of abortion. This study is to assess the knowledge, attitudes, and behavior regarding abortion in young adults.

Methods: This is a descriptive cross-sectional study. The subjects were young women aged 18-24 years old who were fulfilled by inclusion and exclusion criteria. The knowledge, attitudes, and behavior were assessed using questionnaire. The results were analyzed using statistical program.

Results: The total subjects recruited in this study were 55 subjects. Twenty-eight (50.9\%) of subjects has a good knowledge and 27 (49.1\%) of subjects had a moderate knowledge. Twenty-nine (52.7\%) subjects had moderate attitudes and 36.4\% of subjects had good attitude. Thirty (54.5\%) of subjects had a good behavior regarding abortion.

Conclusion: Most of the subjects had good level of knowledge and moderate attitude toward abortion.

Keywords: Knowledge, Attitudes, Practice, Abortion, Young adult.

(C) 2019 The Authors. Published by Innovare Academic Sciences Pvt Ltd. This is an open access article under the CC BY license (http://creativecommons. org/licenses/by/4. 0/) DOI: http://dx.doi.org/10.22159/ajpcr.2019.v12i7.32906

\section{INTRODUCTION}

The World Health Organization and the Society for Adolescent Medicine define young adults in the age range from 18 to 24 years old as reported by America's Young Adult. Abortion is a term defined as termination of pregnancy before the fetus could live outside the womb (previable) or $<20$ weeks. Unsafe abortion is the third leading cause of death in the world. In Indonesia, maternal mortality rate due to abortion was $11 \%$ which reached 390/100,000 live births; it was a huge number even for Asia and world [1-3].

Nationally, abortion rate in Indonesia was $4 \%$, which most of them, about $6.54 \%$ were intentional abortion. In 2011, BKKBN estimated that the number of abortion was reaching 2.4 million and 800,000 of them occurred among young adults. While the IPPA estimated that each year, there were 2.3 million cases of abortion, of which $20 \%$ of them was happened in young adults. As many as, $27 \%$ of young adults demanding the unsafe abortion [4-7]

Indonesian Family Planning Association of Aceh (IFPA) showed that there was high interest of citizens in Banda Aceh either regarding abortion itself or traditional drugs induced abortion. In 2011, IFPA released the high interest of citizens in Banda Aceh regarding abortion issues. In observation of educational programs, dialogues, and discussions with young adult in range of age 26-24 years old and unmarried conducted by IPPA shows the lack of knowledge and understanding in young adults regarding reproductive health issues [2,4-7]. Due to those current conditions, it is interesting to study about this phenomenon. The aim of this study is to evaluate the knowledge, attitude, and behavior of young adults regarding abortion in Banda Aceh, Indonesia.

\section{MATERIALS AND METHODS}

This study is a cross-sectional study to describe the knowledge, attitude, and behavior of young adults regarding abortion in Peunayong sub-district of Kuta Alam, Banda Aceh, Indonesia. Subjects were taken by consecutive sampling from 2016 to 2017.

Inclusion criteria are women 18-24 years old, willing to participate. Incomplete data were excluded. Data were taken by questionnaires modified from the previous study. The validity and reliability of questionnaires had been tested and proven to be valid and reliable.

This study had been approved by the Ethical Committee of Faculty of Medicine Universitas Syiah Kuala, Banda Aceh, Indonesia. The data were collected and were analyzed using statistical analysis.

\section{RESULTS}

Based on the research and analysis of data regarding our knowledge and attitudes in young adults, the researchers concluded as follows of knowledge, attitudes, and behaviors regarding abortion among young adult in Kuta Alam sub-district Peunayong Banda Aceh is dominated by good knowledge in $28(50.9 \%)$ of subjects, good attitudes were in $29(52.7 \%)$ of subjects, and good behavior in

Table 1: The characteristics of subjects

\begin{tabular}{lll}
\hline No. & Variables & $\mathbf{n ~ ( \% ) ~}$ \\
\hline 1 & Age (years old) & \\
& $18-20$ & $16(29.1)$ \\
& $21-24$ & $39(70.9)$ \\
2 & Education & \\
& Senior high school & $43(78.2)$ \\
& Bachelor & $12(21.8)$ \\
3 & Information resources & $15(27.3)$ \\
& Friends & $15(27.3)$ \\
& Health-care professionals & $7(12.7)$ \\
& Teacher & $18(32.7)$ \\
\hline
\end{tabular}


Table 2: Characteristic of knowledge, attitudes, and behavior toward abortion among young adults based on age, education, and information resources

\begin{tabular}{|c|c|c|c|c|c|c|c|c|}
\hline \multirow[t]{2}{*}{ No. } & \multirow[t]{2}{*}{ Variables } & \multicolumn{2}{|c|}{ Knowledge, n (\%) } & \multicolumn{3}{|c|}{ Attitudes, n (\%) } & \multicolumn{2}{|c|}{ Behavior, n (\%) } \\
\hline & & Good & Moderate & Good & Moderate & Bad & Good & Moderate \\
\hline \multirow[t]{3}{*}{1} & Age (years old) & & & & & & & \\
\hline & $18-20$ & $5(31.2)$ & $11(68.8)$ & $2(12.5)$ & $12(75)$ & $2(12.5)$ & $7(43.8)$ & $9(56.2)$ \\
\hline & $21-24$ & $23(59)$ & $16(41)$ & $18(42.6)$ & $17(43.6)$ & $4(10.3)$ & $23(59)$ & $16(41)$ \\
\hline \multirow[t]{3}{*}{2} & Education & & & & & & & \\
\hline & Senior high school & $20(46.5)$ & $23(53.5)$ & $16(37.2)$ & $22(51.2)$ & $5(11.6)$ & $23(53.5)$ & $20(46.5)$ \\
\hline & Bachelor & $8(66.7)$ & $4(33.3)$ & $4(33.3)$ & $7(58.3)$ & $1(8.3)$ & $7(58.3)$ & $5(41.7)$ \\
\hline \multirow[t]{5}{*}{3} & Information resources & & & & & & & \\
\hline & Friends & $3(20)$ & $12(80)$ & $4(26.7)$ & $9(60)$ & $2(13.3)$ & $3(20)$ & $12(80)$ \\
\hline & Health-care professionals & $9(60)$ & $6(40)$ & 7 (46.7) & $6(40)$ & $2(13.3)$ & $9(60)$ & $6(40)$ \\
\hline & Teacher & $7(100)$ & $0(0)$ & $3(42.9)$ & $4(57.1)$ & $0(0)$ & $6(85.7)$ & $1(14.3)$ \\
\hline & Electronic media & $9(50)$ & $9(50)$ & $6(33.3)$ & $10(55.6)$ & $2(11.1)$ & $12(66.7)$ & $6(33.3)$ \\
\hline
\end{tabular}

$30(54.5 \%)$ of subjects. The characteristics of the subject can be shown in Table 1.

Overview of knowledge, attitudes, and behaviors regarding abortion can be shown in Table 2. Based on age among a young adult in Kuta Alam sub-district Peunayong Banda Aceh, the knowledge, attitudes, and behavior of the group age of 18-20 years old, dominated by the good knowledge $11(68.8 \%)$ subjects, good attitudes 12 subjects (75\%), and good behavior 9 subjects (56.2\%). The group age of 2124 years old dominated by good knowledge 23 subjects (50.9\%), good attitudes in 17 subjects (43.6\%), and good behavior in 23 subjects (59\%).

Overview of knowledge, attitudes, and behaviors regarding abortion based on the level of education among senior high school young adults in the Kuta Alam, sub-district of Peunayong Banda Aceh was good knowledge 23 subjects, good attitudes 22 subjects, and good behavior in 23 subjects. Among bachelor adults, subjects who had good knowledge were eight subjects, followed by good behavior in subjects.

Based on information resources regarding abortion, the level of knowledge of young adults who received information from peer group was mostly in good knowledge (80\%) and good behavior (80\%). In the group of young adults who received information from health-care professionals was mostly in good knowledge $(60 \%)$, good attitudes $(46.7 \%)$, and good behavior (60\%). Young adults who received information from teacher or lecturer, all of them have good knowledge $(100 \%)$, but the subjects who have good attitudes $(57.1 \%)$ and good behavior $85.7 \%$.

In the group of young adults who receive information form electronic media was mostly having good knowledge (85.7\%), good attitudes (55.6\%), and good behaviors (66.7\%).

\section{DISCUSSION}

Studies showed if contraception need is unmet, the rate of unplanned pregnancies will rise; hence, it will provoke the act of abortion. Abortion is a social problem covering the legal, ethical, economic, and philosophical aspect. Historically, all religions forbid the act of abortion $[1,3]$.

From Islamic perspective, there is an acceptable condition for abortion due to medical indication and gestational age appropriate for abortion. Most Islamic ulama agree if valid reason is applicable for abortion before appropriate gestational age [8-10]. Contraception use is associated with several demographic factors, as stated in one of the studies in Korea [11].

Banda Aceh is one of the Islamic cities in Indonesia and keeping the Muslim value very high. From this study, we found that $100 \%$ of respondent have good knowledge about abortion. Most of them retrieved the information from electronic media. The development of electronic media is really fast currently, with unlimited internet accessibility making people easier to get information. Even though it will be hard to get information from Aceh society or people, the electronic media globalization could make anyone access unlimited information, including the information considered taboo in society $[4,8,9]$. Use of contraceptive methods are influenced by various factors. Health-care provider should find the unmet needs of individual women to find suitable family planning methods [12].

The strength of this study is one of the studies which brave enough to explore the knowledge and information considered taboo from Islamic society in Aceh. The limitation of this study is that there were some subjective issues and enthusiasm of the subjects in participating this study. There were some issues of the hesitation among the subjects toward the information that they shared.

\section{CONCLUSION}

Mostly of young adults in Banda Aceh have an appropriate knowledge, attitudes, and behavior regarding abortion issues. In this study, there were some of the subjects lacking in knowledge, attitudes, and behavior, perhaps due to some of the external environment that did not be discussed in this study.

\section{AUTHORS' CONTRIBUTIONS}

Eka Rusdianto Gunardi is the main author who developed the concept of this research, Erik A Rahman helped with data gathering and processing, Biran Affandi was supervising the manuscript writing and citation, and Muhammad Ikhsan contributed to manuscript writing, editing, and finalizing.

\section{CONFLICTS OF INTEREST}

The authors have no conflicts of interest.

\section{REFERENCES}

1. Salgado A, Cheetham N. The Sexual and Reproductive Health of Youth: A Global Snapshot. Washington, DC: Advocates for Youth; 2003. p. 2005-15.

2. Organization Health Organization. Safe Abortion: Technical and Policy Guidance for Health Systems. Geneva: World Health Organization; 2003.

3. Wulf D. Sharing Responsibility: Women Society and Abortion Worldwide. New York: The Institute; 1999.

4. Astuti J. Pengaruh Karakteristik Siswa Dan Sumber Informasi Terhadap Kecenderungan Melakukan Hubungan Seksual Pranikah Pada Siswa Sma Negeri Di Banda Aceh Tahun. 2008. Theses; 2009.

5. Muadz M. Kurikulum and Modul Peelatihan Pengelolahan Pusat Informasi dan Konseling Kesehatan Reproduksi Remaja (PIK-KRR). Jakarta: Direktorat Remaja dan Perlindungan Hak-hak Reproduksi; 2008.

6. Silalahi E. Karakteristik ibu pasangan usia subur yang mengalami 
abortus di rumah sakit santa elisabeth medan tahun 2010-2013. Gizi Kesehatan Reprod Epidemiol 2015;1:27-9.

7. Zulfawati R, Damayanti FN, Purwanti IA. Studi kualitatif tentang perilaku pacaran siswi sma pasca tindakan aborsi di kecamatan belik. J Kebidanan 2013;2:93-7.

8. Baykan Z, Çetinkaya F, Naçar M, Poyrazoğlu S. The perspective of women regarding induced abortion in an Islamic country (Turkey): A descriptive study. J Womens Health Care 2015;4:255.

9. Hedayat KM, Shooshtarizadeh P, Raza M. Therapeutic abortion in
Islam: Contemporary views of muslim shiite scholars and effect of recent Iranian legislation. J Med Ethics 2006;32:652-7.

10. Raghavan C, Levine JP. Self-determination and Women's Rights in Muslim Societies. Massachusetts: UPNE; 2012.

11. Kim K, Park H. Demographic factors associated with oral contraceptive use in Korean women. Int J Pharm Pharm Sci 2016;8:299-301.

12. Missiriya S, Priya M, Pavithra G, Priyanka K, Sandhiya R. Assess the knowledge and practice of reproductive aged tribal women on family welfare methods. Int J Pharm Pharm Sci 2017;9:121-4 